\title{
Burrowing behaviour of the Baltic clam Macoma balthica: effects of sediment type, hypoxia and predator presence
}

\author{
Minna Tallqvist* \\ Åbo Akademi University, Department of Biology/Environmental and Marine Biology, 20500 Åbo, Finland
}

\begin{abstract}
Burial in sediment-dwelling clams is affected by morphological features, such as shell shape and size, but also by biotic and abiotic factors, such as predator presence, oxygen deficiency and sediment characteristics. In the Baltic Sea, oxygen deficiency is a severe problem not only in the deep basins, but also in the shallow coastal areas, due to eutrophication. In the species-poor Baltic Sea, the bivalve Macoma balthica (L.) is a key species in both shallow and deep bottoms. This paper analyzes the impact of biotic and abiotic factors on the burrowing behaviour of $M$. balthica. Experiments were conducted to study the importance of sediment type, hypoxia, predator presence and algal mats on the burrowing behaviour (start of burial and burial velocity) of $M$. balthica. Results show that sediment type and the presence of the predatory isopod Saduria entomon did not affect the burrowing behaviour of $M$. balthica. In contrast, the burrowing behaviour was negatively influenced by hypoxia and drifting algae. Physical disturbance and oxygen decifiency are important forces that may displace $M$. balthica in the sediment and make it susceptible to predators at the sediment surface. Burial in the sediment is the only way in which infauna bivalves may escape predators, and this study shows that burrowing capability can be affected by poor environmental conditions.
\end{abstract}

KEY WORDS: Macoma balthica $\cdot$ Burial $\cdot$ Eutrophication $\cdot$ Hypoxia $\cdot$ Predation $\cdot$ Algal mats

\section{INTRODUCTION}

The Baltic clam Macoma balthica (L.) is 1 of 5 bivalve species found in the brackish northern Baltic Sea. It is the dominant bivalve in shallow and deep soft bottoms, and is considered a key species in these habitats (Segerstråle 1962). Eutrophication is an escalating problem in the area (Bonsdorff et al. 1997), inducing hypoxic conditions in shallow coastal areas (days to weeks). Severe hypoxia and anoxia have detrimental effects on benthic communities, especially for infaunal species with limited mobility (Vismann 1992, Diaz \& Rosenberg 1995). Stress responses are often speciesspecific, and generally $M$. balthica is considered tolerant of hypoxia (Dries \& Theede 1974). Drifting algal mats occur frequently in the northern Baltic Sea, vary-

*E-mail: minna.tallqvist@abo.fi ing seasonally in abundance and density (Bonsdorff 1992). Algal mats induce hypoxic conditions and have more severe effects on infauna than hypoxia alone (Norkko \& Bonsdorff 1996a).

Infauna that inhabit soft sediments use these as foraging grounds and as refuges from predators. Species with limited mobility may change their vulnerability to predators by altering their burial depth in the sediment. In Macoma balthica, a facultative suspension and deposit feeder, decreased burial depth enhances the feeding area but increases the vulnerability to lethal and sublethal predation (Zwarts 1986, Zwarts et al. 1994). Burial depth can therefore be considered as a trade-off between feeding and predator avoidance. In areas affected by hypoxia and algal mats, infauna are often forced to the sediment surface and can thus be more vulnerable for epibenthic predators, such as flatfish or crustaceans (Jørgensen 1980, Baden et al. 1990, Norkko \& Bonsdorff 1996a,b). Fishes have been shown 
to use these areas as foraging grounds, moving in and out of hypoxic areas (Pihl et al. 1992, Rahel \& Nutzman 1994).

Occasionally, infaunal bivalves may be forced to the sediment surface (by disturbance, hypoxia, algal mats); their capability to reburrow after such events was investigated in this study. The importance of bivalve size (shell length) and sediment type (sand vs mud) on the burrowing behaviour of Macoma balthica was studied in 2 experiments. Eutrophication-induced changes in burrowing behaviour was studied in 2 other experiments; 1 investigating the importance of hypoxia and predator presence, and 1 investigating the role of algal mats. The isopod Saduria entomon was used as a predator in this study. S. entomon is known to be a predator and siphon-cropper of $M$. balthica (Ejdung \& Bonsdorff 1992, Bonsdorff et al. 1995), as well as of other infauna species (Sandberg \& Bonsdorff 1990). S. entomon is tolerant of hypoxia, anoxia and hydrogen sulphide (Hagerman \& Szaniawska 1990, 1992, Vismann 1991) and is abundant at mud sites together with $M$. balthica.

Burrowing behaviour was studied using 2 parameters; time for the start of reburial and burial velocity. The aim of this study was to increase knowledge of sublethal changes in infauna during and after hypoxic events, and to evaluate the importance of such changes to food-web interactions.

\section{MATERIALS AND METHODS}

Macoma balthica. Bivalves were sampled with sediment grabs (Ekman-Birge grab or a boxcorer) or with a shovel at shallow depths. They were extracted from the field sediment using a $1 \mathrm{~mm}$ mesh-size sieve, and then stored in tanks in the laboratory until use in experiments. The storage tanks were kept in temperature-controlled rooms at the same salinity ( 5 to $6 \%$ ) as that used in the experiments. The temperature was adjusted to ambient water temperature, and thus the temperature varied between experiments (Table 1). Sediment from the sampling sites was added to the storage tanks, and bivalves were kept in the same type of sediment from which they had been sampled. Acclimation time (time of storage in laboratory) varied between experiments (Table 1), but all bivalves within an experiment were sampled on the same day. After each experiment the length of the bivalves was measured with a calliper. All experiments were conducted under a 12:12 h light:dark photoperiod. Five replicate sediment samples were taken to determine the organic content in sediments. The sediment was dried for $24 \mathrm{~h}$ in $100^{\circ} \mathrm{C}$ to determine dry weight (DW), after which the samples were incinerated for $3 \mathrm{~h}$ at $500^{\circ} \mathrm{C}$ to determine ash-free dry weight. The experimental set-up varied between the experiments, depending on methods used and questions asked. The start of burial was registered when a bivalve lifted from its horizontal position to an upright position to start burrowing into the sediment, and burial time was determined as the time interval between start of burial and disappearance of the shell under the sediment surface.

Importance of shell length and sediment type (Expts 1 and 2). The importance of shell length on burial behaviour was studied in Expt 1 using 2 sediment types. Different-sized Macoma balthica were sampled at 2 sites, 1 with sandy sediment and 1 with mud. Sediment was sampled at each site and sieved through a $1 \mathrm{~mm}$ mesh-size sieve to exclude large predators. Bivalves sampled from the sandy habitat burrowed into sand, and bivalves sampled from the muddy habitat burrowed into mud treatments. Experiment aquaria were $1 \mathrm{l}$ plastic buckets with $5 \mathrm{~cm}$ of sediment covered with natural seawater (Table 1). Ten separate aquaria were used for each treatment and 1 bivalve at a time was allowed to burrow in each aquarium. Bivalves that did not burrow within $5 \mathrm{~h}$ were excluded from the analysis, resulting in 180 bivalves successfully burrowing in mud and 170 bivalves successfully burrowing in sand. The number of bivalves not burrowing within the time limit was $<10$ for both sediment types. Oxygen content was kept high by bubbling air into each aquaria.

About $1 \mathrm{~kg}$ of sediment of each sediment type was dried for $24 \mathrm{~h}$ at $100^{\circ} \mathrm{C}$ for grain-size analysis. The dried sediment was sieved onto a Franz separator with the mesh-sizes $1.000,0.500,0.250,0.125,0.074$ and $0.062 \mathrm{~mm}$.

In order to exclude size and site factors, the importance of sediment type was studied in Expt 2. Macoma balthica of an approximately similar size $(11 \mathrm{~mm})$, sampled at the sand site, were allowed to bury in both mud and sand sediment. The sediment that was used was sampled at the same time and at the same sites as for Expt 1. The experiment was done in similar aquaria as in Expt 1, with 1 bivalve per aquarium (Table 1). A total of 80 bivalves were allowed to burrow, 40 in each sediment type.

Importance of predation and hypoxia (Expt 3). Expts 3 and 4 were conducted in only 1 type of sediment to minimize the number of treatments. Macoma balthica and Saduria entomon were sampled from muddy sediment and the experiment was conducted in mud. The animals were kept in storage tanks with mud sediment and normoxic oxygen conditions until use in the experiment. Bivalves were treated with either hypoxia $\left(<1 \mathrm{mg} \mathrm{l}^{-1} \mathrm{O}_{2}\right)$ or normoxia for $13 \mathrm{~d}$. The hypoxic conditions were maintained by bubbling $\mathrm{N}_{2}$ into seawater filled aquaria and oxygen saturation was automatically regulated (Radiometer PHM71 Mk2 
Table 1. Macoma balthica. Experimental set-up and hydrographical conditions in Expts 1 to 4. Treatment: sand (S), mud (M), control $(\mathrm{C})$, hypoxia $(\mathrm{H})$, predator $(\mathrm{P})$, hypoxia + predator $(\mathrm{HP})$, algal mat $(\mathrm{A})$, normoxia $(\mathrm{N})$

\begin{tabular}{|c|c|c|c|c|}
\hline & Expt 1 & Expt 2 & Expt 3 & Expt 4 \\
\hline Treatment & $\begin{array}{l}\text { (S) } \\
\text { (M) }\end{array}$ & $\begin{array}{l}\text { (S) } \\
\text { (M) }\end{array}$ & $\begin{array}{l}(\mathrm{C}) \\
(\mathrm{H}) \\
(\mathrm{P}) \\
(\mathrm{HP})\end{array}$ & $\begin{array}{l}\text { (C) } \\
\text { (A) }\end{array}$ \\
\hline No. of replicates & $170(\mathrm{~S}), 180(\mathrm{M})$ & 40 & 9 & 6 \\
\hline Aquarium size $(\mathrm{cm})$ & $10 \times 10$ & $10 \times 10$ & $10 \times 10$ & $20 \times 30$ \\
\hline No. of $M$. balthica/replicate & 1 & 1 & 5 & 10 \\
\hline Acclimation time (wk) & 1 & 1 & 8 & 4 \\
\hline Experiment time & $5 \mathrm{~h}$ & $24 \mathrm{~h}$ & $13 \mathrm{~d}$ & $10 \mathrm{~d}$ \\
\hline \multicolumn{5}{|l|}{ Shell length (mm) } \\
\hline Mean \pm SE & $\begin{array}{l}8.01 \pm 0.26(\mathrm{~S}) \\
6.64 \pm 0.23(\mathrm{M})\end{array}$ & $\begin{array}{l}10.87 \pm 0.14(\mathrm{~S}) \\
10.93 \pm 0.14(\mathrm{M})\end{array}$ & $\begin{array}{l}10.99 \pm 0.37(\mathrm{C}) \\
11.86 \pm 0.34(\mathrm{H}) \\
11.13 \pm 0.38(\mathrm{P}) \\
11.33 \pm 0.33(\mathrm{HP})\end{array}$ & $\begin{array}{l}11.15 \pm 0.20(\mathrm{C}) \\
11.38 \pm 0.18(\mathrm{~A})\end{array}$ \\
\hline Min.-max. & $\begin{array}{l}2.47-15.34(\mathrm{~S}) \\
2.59-14.43(\mathrm{M})\end{array}$ & $\begin{array}{l}9.28-13.23(\mathrm{~S}) \\
8.60-12.80(\mathrm{M})\end{array}$ & $\begin{array}{l}5.96-16.42(\mathrm{C}) \\
7.71-16.73(\mathrm{H}) \\
7.03-16.72(\mathrm{P}) \\
7.52-15.39(\mathrm{HP})\end{array}$ & $\begin{array}{l}8.58-14.5(\mathrm{C}) \\
9.00-14.07(\mathrm{~A})\end{array}$ \\
\hline \multicolumn{5}{|l|}{ Wet weight $(g)$} \\
\hline Mean $\pm \mathrm{SE}$ & $\begin{array}{l}- \\
-\end{array}$ & $\begin{array}{l}0.2226 \pm 0.01(\mathrm{~S}) \\
0.2321 \pm 0.01(\mathrm{M})\end{array}$ & $\begin{array}{l}0.2454 \pm 0.03(\mathrm{C}) \\
0.3019 \pm 0.03(\mathrm{H}) \\
0.2543 \pm 0.03(\mathrm{P}) \\
0.2563 \pm 0.02(\mathrm{HP})\end{array}$ & $\begin{array}{l}0.2766 \pm 0.02(\mathrm{C}) \\
0.2858 \pm 0.01(\mathrm{~A})\end{array}$ \\
\hline Min.-max. & $\begin{array}{l}- \\
-\end{array}$ & $\begin{array}{l}0.1287-0.3991(\mathrm{~S}) \\
0.0985-0.4121(\mathrm{M})\end{array}$ & $\begin{array}{l}0.0303-0.7934(\mathrm{C}) \\
0.0729-0.8470(\mathrm{H}) \\
0.0546-0.6885(\mathrm{P}) \\
0.0592-0.6226(\mathrm{HP})\end{array}$ & $\begin{array}{l}0.1048-0.5734(\mathrm{C}) \\
0.1214-0.5329(\mathrm{~A})\end{array}$ \\
\hline Sediment type & $(\mathrm{S}),(\mathrm{M})$ & $(\mathrm{S}),(\mathrm{M})$ & $(\mathrm{M})$ & $(\mathrm{S})$ \\
\hline Sediment depth $(\mathrm{cm})$ & 5 & 5 & 5 & 6 \\
\hline Organic content (\%) & $\begin{array}{l}0.38 \pm 0.02(\mathrm{~S}) \\
8.41 \pm 0.05(\mathrm{M})\end{array}$ & $\begin{array}{l}0.38 \pm 0.02(\mathrm{~S}) \\
8.41 \pm 0.05(\mathrm{M})\end{array}$ & $5.32 \pm 0.04$ & $0.50 \pm 0.02$ \\
\hline Temperature $\left({ }^{\circ} \mathrm{C}\right)$ & 7 & 13 & 12 & 5 \\
\hline Salinity (ppt) & $5.5(\mathrm{~S}), 5.3(\mathrm{M})$ & $5.5(\mathrm{~S}, \mathrm{M})$ & 6.0 & 5.2 \\
\hline $\mathrm{pH}$ & $8.4(\mathrm{~S}), 8.3(\mathrm{M})$ & $8.4(\mathrm{~S}, \mathrm{M})$ & $\begin{array}{l}7.96 \pm 0.02(\mathrm{~N}) \\
7.86 \pm 0.01(\mathrm{H})\end{array}$ & $8.2(\mathrm{C}, \mathrm{A})$ \\
\hline Oxygen $\left(\mathrm{mg} \mathrm{l}^{-1}\right)$ & $\begin{array}{l}11.89(\mathrm{~S}) \\
11.58(\mathrm{M})\end{array}$ & $\begin{array}{l}10.10(\mathrm{~S}) \\
10.00(\mathrm{M})\end{array}$ & $\begin{array}{l}10.33 \pm 0.04(\mathrm{~N}) \\
0.56 \pm 0.07(\mathrm{H})\end{array}$ & Fig. 1 \\
\hline Statistics & Linear regression & Mann-Whitney $U$-test & Nested ANOVA & Nested ANOVA \\
\hline
\end{tabular}

analyser with E5047 oxygen electrode). Start of burial and burial time was determined for bivalves in 4 treatments: (1) pre-treatment in normoxia, burrowing in normoxia; (2) pre-treatment in hypoxia, burrowing in normoxia; (3) pre-treatment in normoxia, burrowing in normoxia; with predator present, (4) pre-treatment in hypoxia, burrowing in normoxia with predator present. In this experiment the same aquaria were used as in Expts 1 and 2, but 5 bivalves were allowed to burrow in each aquarium, and in predator treatments $1 S$. entomon was added to each aquarium (Table 1). Nine replicates were used for each treatment.

Importance of drifting algae (Expt 4). The effect of algal mats on the burial behaviour of Macoma balthica was studied in Expt 4. Two different treatments were used: sand sediment (control), and sand sediment with algal mats. Bivalves and sediment were sampled at a shallow sandy site. The experiment was conducted in $11 \mathrm{l}$ aquaria with a $6 \mathrm{~cm}$ sediment layer and 10 adult bivalves (11 to $12 \mathrm{~mm}$ in length) per aquarium (Table 1). The experiment time was $10 \mathrm{~d}$ and oxygen saturation and temperature was registered both under and above the algal mat and in the bottom water layer in the control treatment. The algae were collected $1 \mathrm{~d}$ before the start of the experiment at a sandy bottom site with loose-lying, drift algae. The algal mat consisted mainly of species of brown and green algae (Pilayella littoralis, Cladophora glomerata) and was added to the aquaria at a wet weight of $130 \mathrm{~g}$ per aquarium (2160 $\mathrm{g} \mathrm{WW} \mathrm{m}^{-2}$ ), corresponding to high densities of algal mats that can be found in the field (Bonsdorff 1992, Norkko \& Bonsdorff 1996b). At the 


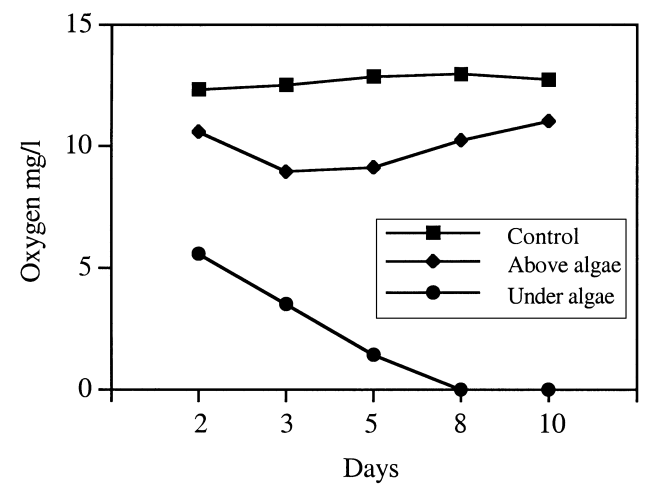

Fig. 1. Oxygen conditions ( $\mathrm{mg} \mathrm{l}^{-1}$ ) in control and algal treatments in Expt 4

end of the experiment, the algae were removed from the sediment surface and dried for $3 \mathrm{~d}$ at $60^{\circ} \mathrm{C}$ for dry weight. The mean DW of algae in the aquaria was $19.30 \pm 0.85 \mathrm{~g}$, (mean $\pm \mathrm{SE})$, corresponding to $322 \mathrm{~g}$ DW m${ }^{-2}$. The temperature was $4.5 \pm 0.1^{\circ} \mathrm{C}$ in the control treatment, and $4.5 \pm 0.1^{\circ} \mathrm{C}$ above and $5.1 \pm 0.1^{\circ} \mathrm{C}$ under the algae in the algal treatment. Increased temperature under algal mats under experimental conditions has also been recorded by Norkko \& Bonsdorff (1996a). The oxygen conditions are presented in Fig. 1.

After $10 \mathrm{~d}$, the number of bivalves at the sediment surface was registered for both treatments. The bivalves were sieved out, the water was changed in both treatments to fresh normoxic water, and the bivalves were allowed to reburrow.

Numerical and statistical analysis. Burial-time data was used to calculate burial velocity (Sakurai et al. 1996) as shell length (mm)/burial time (s).

The data was tested for normality and homogenity of variances. Parametric tests were used if these conditions were met, in other cases a nonparametric test was chosen. In all cases, a significance level of $\mathrm{p}<0.05$ was used. In Expt 1 the relationship between shell length and burrowing behaviour was tested by linear regression. The slopes of regression lines were compared to reveal possible significant differences in burial behaviour between sand and mud sediment (Fowler \& Cohen 1990).

In Expt 2, the 10 aquaria were tested against each other (Kruskal-Wallis test), and when there was no difference between the aquaria, each bivalve was used as a replicate when testing differences between treatments by the nonparametric Mann-Whitney $U$-test.

A nested ANOVA with fixed factors was used to test the differences between treatments in Expts 3 and 4, where there were several bivalves per aquarium, and the aquaria were thus nested within the treatments.

\section{RESULTS}

\section{Importance of shell length (Expt 1)}

Linear regression analysis revealed a significant positive relationship between the shell length of Macoma balthica and the start of burial in both sediment types (Fig. 2a). Burial time was also significantly related to shell length in both sand and mud sediment (Fig. 2b). However, the $\mathrm{R}^{2}$ values for these equations were very low, indicating poor predictive power. There was no significant difference in start of burial or time of burial between sand and mud sediment when comparing slopes of the regression lines.

The grain size results (given as the relative fraction of the total sample) were $12.8 \%$ on $0.250 \mathrm{~mm}, 82.3 \%$ on $0.125 \mathrm{~mm}$ and $4.9 \%$ on the $0.074 \mathrm{~mm}$ mesh-size sieve for the sand sediment and $3.1 \%$ on $0.250 \mathrm{~mm}$,

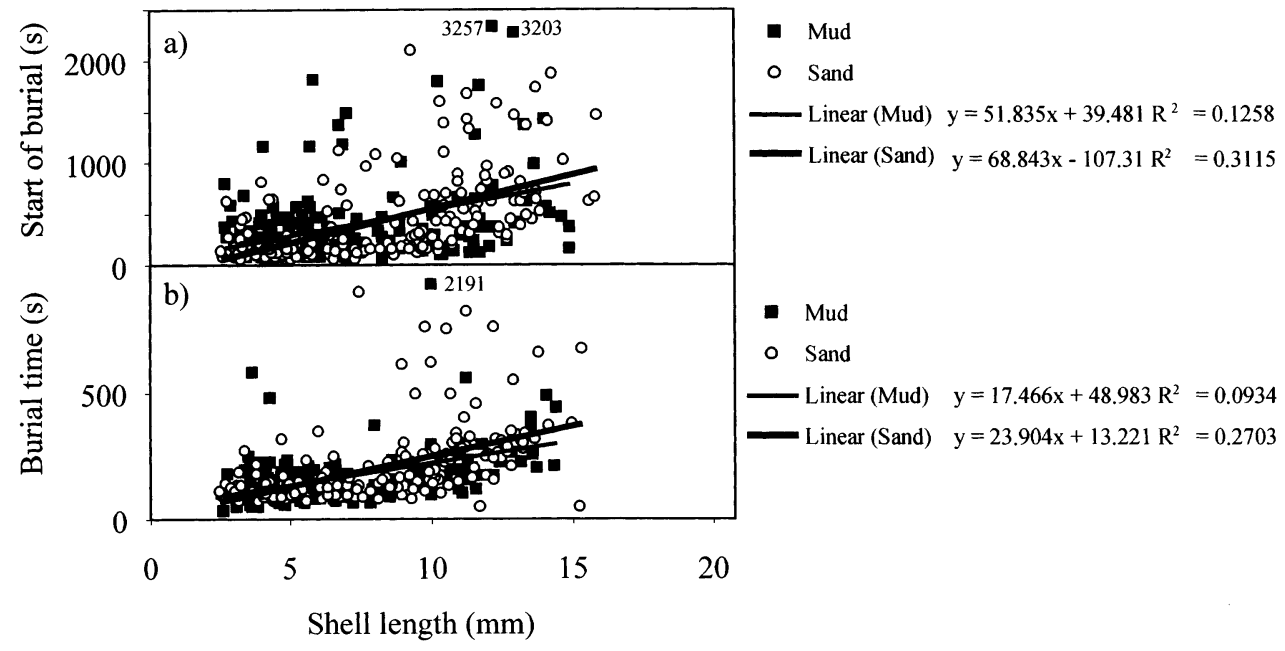

Fig. 2. Macoma balthica. Expt 1. (a) Start of burial, and (b) burial time as a function of shell length in sand and mud sediment 
$49.8 \%$ on $0.125 \mathrm{~mm}, 31.4 \%$ on $0.074 \mathrm{~mm}, 6.6 \%$ on $0.062 \mathrm{~mm}$ and $9.1 \%$ on the $<0.062 \mathrm{~mm}$ mesh-size sieve in the mud sediment.

\section{Importance of sediment type (Expt 2)}

There was no significant difference in burial behaviour of Macoma balthica between different aquaria (Kruskal-Wallis test), and therefore, each bivalve was used as a replicate when comparing means between the 2 sediment types. The start of burial was $292 \pm 33 \mathrm{~s}$ (mean $\pm \mathrm{SE}$ ) in sand and $321 \pm 62 \mathrm{~s}$ in mud (Fig. 3a). Mean burial velocity was $0.089 \pm 0.005 \mathrm{~mm} \mathrm{~s}^{-1}$ in sand and $0.068 \pm 0.005 \mathrm{~mm} \mathrm{~s}^{-1}$ in mud (Fig. 3b). There was no significant difference in the burrowing behaviour parameters between the sediment treatments (MannWhitney $U$-test).

\section{Importance of predation and hypoxia (Expt 3)}

The nested ANOVA analysis revealed a significant difference between treatments for the start of burial $(\mathrm{p}=0.0338, F$-value $=3.268)$ and for burial velocity $(\mathrm{p}=$ $0.0001, F$-value $=21.212$ ). The analysis revealed no significant effect of the aquaria for these parameters. There was a significant difference in the time of the start of burial of Macoma balthica (Fig. 4a) between the predator $(256 \pm 34 \mathrm{~s})$ and hypoxia $(507 \pm 62 \mathrm{~s})$

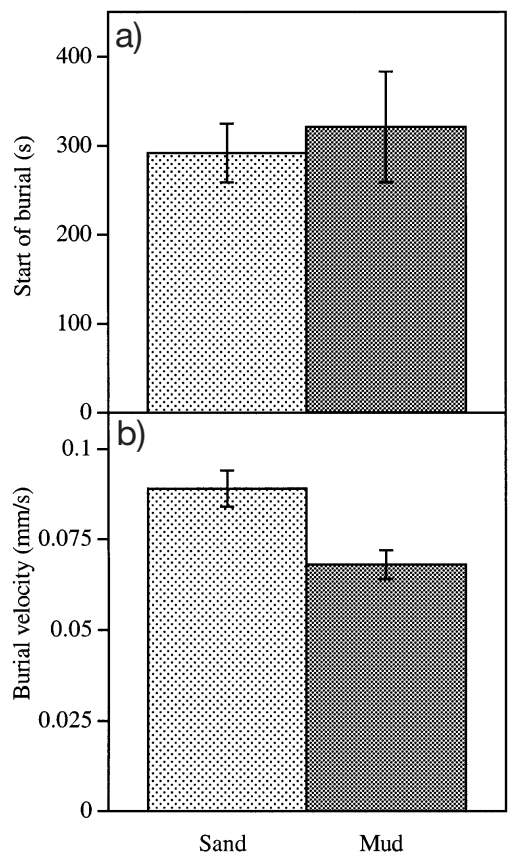

Fig. 3. Macoma balthica. Expt 2. (a) Mean ( \pm SE) start of burial, and (b) burial velocity $\left(\mathrm{mm} \mathrm{s}^{-1}\right)$ in sand and mud sediment

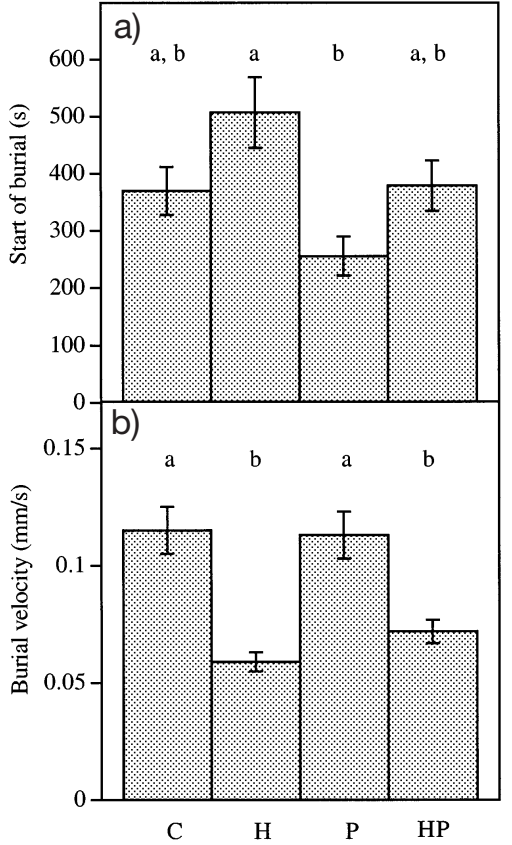

Fig. 4. Macoma balthica. Expt 3. (a) Mean ( \pm SE) start of burial, and (b) burial velocity $\left(\mathrm{mm} \mathrm{s}^{-1}\right)$ for in control (C), hypoxia $(\mathrm{H})$, predator $(\mathrm{P})$ and hypoxia + predator $(\mathrm{HP})$ treatments. Significant differences $(\mathrm{p}<0.05)$ between treatments are indicated by different letters ( $a$ and $b$ )

(Student-Newman-Keuls comparison) treatments. The time for start of burial was $370 \pm 42 \mathrm{~s}$ in the control treatment and $379 \pm 44 \mathrm{~s}$ in the hypoxia + predator treatment. Mean burial velocity differed between the control treatment $\left(0.115 \pm 0.01 \mathrm{~mm} \mathrm{~s}^{-1}\right)$ and the hypoxia $\left(0.059 \pm 0.004 \mathrm{~mm} \mathrm{~s}^{-1}\right)$ and hypoxia + predator $\left(0.072 \pm 0.005 \mathrm{~mm} \mathrm{~s}^{-1}\right)$ treatments (Fig. $\left.4 \mathrm{~b}\right)$. The predator treatment $\left(0.113 \pm 0.01 \mathrm{~mm} \mathrm{~s}^{-1}\right)$ also differed significantly from hypoxia and hypoxia + predator treatments. There was no significant difference in any of the burial parameters when comparing control to predator treatment or hypoxia to hypoxia + predator treatment. For the start of burial, both predator treatments had lower mean values than the treatments without predators, but the difference was not significant. The mean length of Saduria entomon was $47.0 \pm 1.4 \mathrm{~mm}$ in normoxia and $47.5 \pm 1.5 \mathrm{~mm}$ in the hypoxia treatment.

\section{Importance of drifting algae (Expt 4)}

All bivalves survived in both the control and algal treatment. At the beginning of the experiment all bivalves buried into the sediment. At the end of the experiment all bivalves remained burrowed in the control treatment, but in the algal treatment the mean number of bivalves on the sediment surface was $6.5 \pm 0.92$ (i.e. 


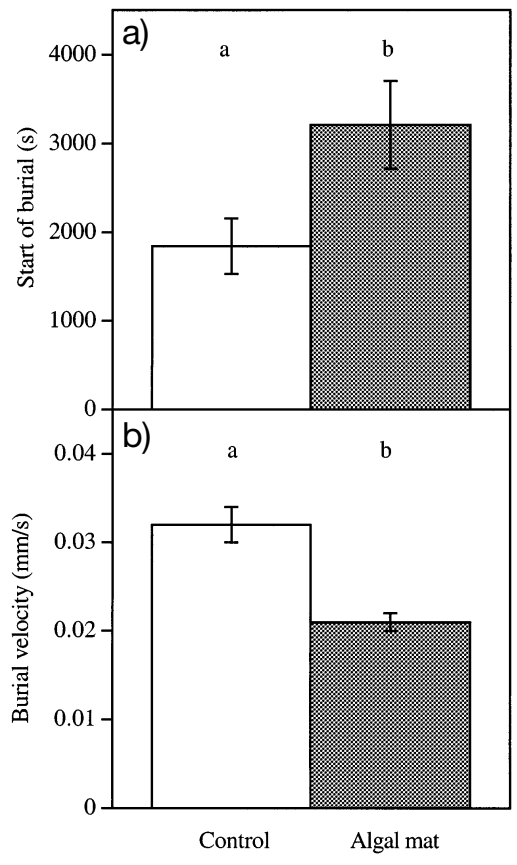

Fig. 5. Macoma balthica. Expt 4. (a) Mean $( \pm \mathrm{SE})$ start of burial, and (b) burial velocity $\left(\mathrm{mm} \mathrm{s}^{-1}\right)$ in control and algal mat treatments. Significant difference $(p<0.05)$ between treatments is indicated by different letters ( $a$ and $b$ )

about $65 \%$ ). There was a significant difference between the control and the algae treatment in the number of Macoma balthica on the sediment surface (Student's $t$-test). There was also a significant difference in the mean number of bivalves that reburrowed: $9.7 \pm 0.22(97 \%)$ in the control treatment compared to $7.8 \pm 0.60(78 \%)$ in the algal treatment after $24 \mathrm{~h}$.

The nested ANOVA analysis revealed a significant difference between treatments for the start of burial $(\mathrm{p}=0.0260, F$-value $=6.815)$ and for burial velocity $(\mathrm{p}=$ $0.0021, F$-value $=16.839)$. The analysis revealed no significant effect of the aquaria for these parameters. The start of burial (Fig. 5a) was significantly faster in the control treatment $(1844 \pm 314 \mathrm{~s})$ than in the algal treatment $(3210 \pm 493 \mathrm{~s})$. The mean burial velocity was $0.032 \pm 0.002 \mathrm{~mm} \mathrm{~s}^{-1}$ in the control treatment and $0.021 \pm 0.001 \mathrm{~mm} \mathrm{~s}^{-1}$ in the algal treatment (Fig. 5b). The mean burial velocity was significantly lower in the algal than in the control treatment.

\section{DISCUSSION}

\section{Burrowing behaviour and shell morphology}

Generally, small specimens burrow more rapidly than larger ones, which was shown to be true for
Macoma balthica in this study. The correlation was not very strong, since the individual variation within size classes was high. In a study by Stanley (1970), burrowing time in the bivalve Donax denticulatus was found to be almost linearly correlated to shell length. Shell shape, length, thickness and ornamentations have been shown to influence the burial rate of bivalves (Stanley 1970). In the present study, the start of burial was found to be significantly related to shell length for $M$. balthica, with increasing time for the start of burial with increasing shell length. As for burial time, the relationship was weak due to large variation between individuals of the same size. The overall time for the start of burial ranged from 50 to $3257 \mathrm{~s}$ (54 min) in this experiment, indicating that large individual variability could be of importance when rapid reburial after disturbance is required. Since the variability was not completely explained by shell length, other factors such as condition and nutrition might explain the variance. This is also supported by the fact that start of burial and burial velocity varied in the control treatments between the different experiments. The start of burial was for example much faster in the sand treatment in Expt 2 compared to the sand treatment without algae in Expt 4. This could have been due to a slightly larger mean length in bivalves in Expt 4 than in Expt 2, but could more probably be due to the fact that Expt 4 was run in late autumn and Expt 2 in early summer and that temperature and acclimation time was different between the 2 experiments. Expt 3 again was run at another biological station than the other experiments, and in sediment that was characterized as mud, but probably differed from the mud sediment in the other experiments due to different sampling sites. Shell length, water temperature, nutritional and reproductional stage of the bivalves, sediment characteristics and possible differences in laboratory conditions could be the reason for differences between the experiments. Within an experiment, however, all bivalves were sampled and handled in the same way.

Shell length has also been related to burial depth which, however, was not measured in this study. Zwarts \& Wanink (1989) showed that burial depth increased with size in Macoma balthica smaller than $10 \mathrm{~mm}$. For larger clams the size did not affect burial depth.

\section{Burrowing behaviour in relation to substrate}

Macoma balthica is found in a variety of soft substrate types in the northern Baltic Sea and can be considered abundant both in sand and mud (Bonsdorff et al. 1996). As shown in Expt 2, reburrowing behaviour did not differ significantly between the 2 sediment 
types. Data from Expt 1 confirm these results. Stanley (1970) points out that sediment type is an important factor affecting the species distribution of bivalves. In coarse-grained sediments, such as exposed tidal sandy beaches, rapidly burrowing species with thick shells are found due to the unstable environment. Muddy substrates are dominated by deep-burrowing deposit feeders. Not only do different species adapt to different sediment types, but the same species might also occur in different types of sediments. In a study of cockles, reburial was affected by sediment type and disturbance, but the effect was size-dependent (CoffenSmout \& Rees 1999). For 3 veneorid bivalve species, the difference in time for the start of burial was found to be non-significant between different grain sizes of sand (coarse, medium, fine and very fine sand) (Sakurai et al. 1996). For 2 of the species, mean burial velocity was significantly affected by grain size. Burrowing behaviour in different substrates (soft sediment vs coarse sand-gravel) has also been studied for 2 freshwater unionids, revealing no difference in burial speed or depth (Nichols \& Wilcox 1997). Results from Expts 1 and 2 show that the ability to reburrow is not significantly different between sand and mud for M. balthica. The mean burial velocity was higher in sand than in mud (Fig. 3), suggesting that it could be slightly easier for $M$. balthica to bury in mud, but due to large individual variation in burial time in both treatments the difference was not found to be significant.

\section{Abiotic factors affecting burrowing behaviour - the role of hypoxia and algal mats}

Infaunal bivalves are generally thought to be quite tolerant of hypoxic conditions (Theede et al. 1969), and $\mathrm{LT}_{50}$ value for Macoma balthica was measured to be over $500 \mathrm{~h}$ at $0.15 \mathrm{mg} \mathrm{l}^{-1} \mathrm{O}_{2}$ at $10^{\circ} \mathrm{C}$ and $17 \%$ salinity (Dries \& Theede 1974). Behavioural changes in benthic organisms might occur at sublethal oxygen levels (Sandberg 1994, Sandberg et al. 1996, Tallqvist et al. 1999). In a unionid bivalve, behavioural changes such as siphon extension, gaping, foot extension and surfacing was recorded at moderate oxygen levels (Sparks \& Strayer 1998).

Hypoxia and algal mats have been shown to cause infauna to emerge to the sediment surface (Jørgensen 1980, Baden et al. 1990, Vismann 1992, Norkko \& Bonsdorff 1996a). Prolonged hypoxia causes faunal mortality, but if the hypoxic conditions are periodic, surviving specimens may be able to reburrow into the sediment. The results from Expt 3 show that hypoxia influenced burial velocity of Macoma balthica in mud, with slower burial in bivalves treated with hypoxia compared to normoxia (Fig. 4). Expt 4 showed that reburial capacity varied between bivalves in sand exposed to normoxic conditions compared to bivalves experiencing hypoxia induced by algal mats (Fig. 5). The start of burial was faster in the control bivalves than those exposed to algal mats, indicating a change in reburial capacity due to the hypoxia induced by the algae. Burial velocity was also slower in $M$. balthica in the algal treatment. Later and slower burial might enhance the exposure time to predators. Since about $20 \%$ of the bivalves from the algal treatment remained unburied (but alive) even when oxygen conditions improved to normoxic levels, the effect might be of importance in predator-prey dynamics. It has been suggested that $M$. balthica can be more susceptible to lethal predation by the crustaceans Saduria entomon and Crangon crangon and the flounder Platichthys flesus after stress by algal mats (Norkko \& Bonsdorff 1996a). In the same study, about $70 \%$ of adult $M$. balthica emerged from the sediment with algal treatment $(17 \mathrm{~d})$, corresponding to $65 \%$ found in the present study (10 d). Norkko \& Bonsdorff (1996a) found $80 \%$ of control bivalves to be buried after 30 min compared to only $11 \%$ of the algal mat bivalves during the same time. Interestingly, they found that the algal mat treatment had a more rapid and severe effect on $M$. balthica emergence than hypoxia, indicating that hypoxia itself is not the only factor affecting the burrowing behaviour of infauna stressed by algal mats. Field experiments demonstrate that $M$. balthica can survive for long periods (9 wk) under algal mats, probably due to its long and flexible siphons that can reach normoxic water (Thiel et al. 1998). Water flow might also buoy up algal mats, which could increase the survival of infauna under the mats by allowing sufficient oxygen supply. Since 2 of 3 bivalve species decreased in abundance in the field study by Thiel et al. (1998), it seems that individual flexibility such as long siphons might be more important for survival than oxygen supply by currents. In the shallow coastal areas in the northern Baltic Sea, algal mats usually lie on the bottom, causing emergence and mortality of infauna that is easy to detect when diving (pers. obs.). However, water flow might be important for long-term survival of the communities, and future studies should also include this parameter in laboratory experiments.

\section{Burrowing responses to predator presence}

Many studies investigate the lethal effects of predators on their prey species, but sublethal effects are less well studied. Sublethal effects on prey species include siphon-cropping of bivalves by juvenile flatfish or crustaceans (de Vlas 1979, Bonsdorff et al. 1995, Sandberg et al. 1996, Tallqvist et al. 1999) and feeding on poly- 
chaete tentacles (Woodin 1982), or changes in prey morphology, physiology, chemistry, life history or behaviour (Sih 1987).

For infauna that are not very mobile (e.g. bivalves), the only effective way to avoid predation by epibenthic predators is to burrow deep into the sediment out of reach of the predators. In nature, however, several factors influence the burial behaviour of bivalves, and predator avoidance can conflict with feeding needs (Zwarts 1986). Lin \& Hines (1994) showed that food concentration affected the feeding mode of Macoma balthica (a facultative deposit and suspension feeder), increasing deposit-feeding and reducing burial depth with lower concentration of suspended food particles. Feeding mode is also affected by the presence of siphon-cropping predators, reducing the deposit feeding activity (Skilleter \& Peterson 1994). Maximal burial depth is directly related to siphon size (Zwarts \& Wanink 1989), but feeding strategies and predator avoidance influence the actual burial depth (Zwarts 1986, Lin \& Hines 1994, Zaklan \& Ydenberg 1997). It has been shown that $M$. balthica burrow deeper in the winter than in the summer because of decreased deposit feeding in winter (Zwarts \& Wanink 1989). Because of decreased predation pressure, bivalves that burrow deeper into the sediment have a higher survival than shallower-burrowing specimens of the same species (Zaklan \& Ydenberg 1997). On the other hand, de Goeij \& Luttikhuizen (1998) showed that an increased burial depth reduced growth and increased mortality in $M$. balthica, probably through lack of sufficient food.

It is advantageous for infauna to reburrow into the sediment as soon as abiotic conditions are better (e.g. when algal mats are washed away, or storms recirculate hypoxic bottom waters) to decrease the risk of lethal predation. There was no significant effect of the presence of the isopod Saduria entomon on reburrowing behaviour of the bivalve Macoma balthica in this study. The mean start of reburial was slower in the treatments without predators than in the presence of predators in both normoxic and hypoxic conditions (Fig. 4a), but due to large individual variations the difference was not significant. Bivalves that are extracted from the sediment by a siphon-cropping predator reburrow within a few minutes (Ansell 1995); however, no control treatments monitoring reburial without predators was used in that study.

\section{Conclusions}

Conflicting demands might influence the behavioural patterns that animals show in response to hypoxia. As a response to algal mats and oxygen defi- ciency, an altered reburrowing behaviour was detected in the infaunal bivalve Macoma balthica. As M. balthica is an important prey species in the Baltic Sea, these effects can alter predator-prey relationships and have effects on higher trophic levels. Future studies should focus on behavioural patterns in animals under the stress of oxygen deficiency. Only by learning more about the sublethal effects of biotic and abiotic stress can we evaluate the importance of possible functional changes that often occur before structural changes can be recorded in the field.

Acknowledgements. I would like to thank the Husö Biological Station and Tvärminne Zoological Station for providing excellent working facilities during the experimental work. Dr Lars Hagerman from Helsingør Marine Laboratory in Denmark is acknowledged for lending me equipment for automatic regulation of oxygen and for instructions in using the equipment. I also want to thank Erik Bonsdorff and Christoffer Boström for valuable comments on the manuscript.

\section{LITERATURE CITED}

Ansell AD (1995) Surface activity of some benthic invertebrate prey in relation to the foraging activity of juvenile flatfishes. In: Eleftheriou A, Ansell AD, Smith CJ (eds) Biology and ecology of shallow coastal waters. Proc 28th Eur Mar Biol Symp. Olsen \& Olsen, Fredensborg, p 245-252

Baden SP, Loo LO, Pihl L, Rosenberg R (1990) Effects of eutrophication on benthic communities including fish: Swedish west coast. Ambio 19:113-122

Bonsdorff E (1992) Drifting algae and zoobenthos-effects on settling and community structure. Neth J Sea Res 30: 57-62

Bonsdorff E, Norkko A, Sandberg E (1995) Structuring zoobenthos: the importance of predation, siphon cropping and physical disturbance. J Exp Mar Biol Ecol 192: 125-144

Bonsdorff E, Diaz RJ, Rosenberg R, Norkko A, Cutter GR Jr (1996) Characterization of soft-bottom benthic habitats of the Åland Islands, northern Baltic Sea. Mar Ecol Prog Ser 142:235-245

Bonsdorff E, Blomqvist EM, Mattila J, Norkko A (1997) Longterm changes and coastal eutrophication. Examples from the Åland Islands and the Archipelago Sea, northern Baltic Sea. Oceanol Acta 20:319-329

Coffen-Smout SS, Rees EIS (1999) Burrowing behaviour and dispersion of cockles Cerastoderma edule L. following simulated fishing disturbance. Fish Res 40:65-72

de Goeij P, Luttikhuizen P (1998) Deep-burying reduces growth in intertidal bivalves: field and mesocosm experiments with Macoma balthica. J Exp Mar Biol Ecol 228: $327-337$

de Vlas J (1979) The annual food intake by plaice and flounder in a tidal flat area in the Dutch Wadden Sea, with special reference to consumption of regenerating parts of macrobenthic prey. Neth J Sea Res 13:117-153

Diaz RJ, Rosenberg R (1995) Marine benthic hypoxia: a review of its ecological effects and the behavioural responses of benthic macrofauna. Oceanogr Mar Biol Annu Rev 33:245-303

Dries RR, Theede H (1974) Sauerstoffmangelresistenz mariner 
Bodenvertebraten aus der westlichen Ostsee. Mar Biol 25: 327-333

Ejdung E, Bonsdorff E (1992) Predation on the bivalve Macoma balthica by the isopod Saduria entomon: laboratory and field experiments. Mar Ecol Prog Ser 88:207-214

Fowler J, Cohen L (1990) Practical statistics for field biology. John Wiley \& Sons, New York

Hagerman L, Szaniawska A (1990) Anaerobic metabolic strategy of the glacial relict isopod Saduria (Mesidotea) entomon. Mar Ecol Prog Ser 59:91-96

Hagerman L, Szaniawska A (1992) Saduria entomon, ecophysiological adaptations for survival in the Baltic. In: Bjørnestad E, Hagerman L, Jensen K (eds) 12th Proc Baltic Mar Biol Symp. Olsen \& Olsen, Fredensborg, p 71-76

Jørgensen BB (1980) Seasonal oxygen depletion in the bottom waters of a Danish fjord and its effect on the benthic community. Oikos 34:68-76

Lin J, Hines AH (1994) Effects of suspended food availability on the feeding mode and burial depth of the Baltic clam, Macoma balthica. Oikos 69:28-36

Nichols SJ, Wilcox DA (1997) Burrowing saves Lake Erie clams. Nature 389

Norkko A, Bonsdorff E (1996a) Altered benthic prey-availability due to episodic oxygen deficiency caused by drifting algal mats. PSZN I: Mar Ecol 17:355-372

Norkko A, Bonsdorff E (1996b) Rapid zoobenthic community responses to accumulations of drifting algae. Mar Ecol Prog Ser 131:143-157

Pihl L, Baden SP, Diaz RJ, Schaffner LC (1992) Hypoxiainduced structural changes in the diet of bottom-feeding fish and Crustacea. Mar Biol 112:349-361

Rahel FJ, Nutzman JW (1994) Foraging in lethal environment: fish predation in hypoxic waters of a stratified lake. Ecology 75:1246-1253

Sakurai I, Seto M, Nakao S (1996) Effects of water temperature, salinity and substrata on burrowing behaviors of the three bivalves Pseudocardium sachalinensis, Mactra chinensis, and Ruditapes philippinarum. Nippon Suisan Gakkaishi 62:878-895

Sandberg E (1994) Does short-term oxygen depletion affect predator-prey relationships in zoobenthos? Experiments with the isopod Saduria entomon. Mar Ecol Prog Ser 103: 73-80

Sandberg E, Bonsdorff E (1990) On the structuring role of Saduria entomon (L.) on shallow water zoobenthos. Ann Zool Fenn 27:279-284

Sandberg E, Tallqvist M, Bonsdorff E (1996) The effects of reduced oxygen content on predation and siphon cropping by the brown shrimp, Crangon crangon. PSZN I: Mar Ecol 17:411-423

Editorial responsibility: Otto Kinne (Editor),

Oldendorf/Luhe, Germany
Segerstråle SG (1962) Investigations on Baltic populations of the bivalve Macoma balthica (L.). II. What are the reasons for periodic failure of recruitment and scarcity of Macoma in deeper waters of the inner Baltic? Commentat Biol Soc Sci Fenn 24:1-26

Sih A (1987) Predators and prey lifestyles: an evolutionary and ecological overview. In: Kerfoot WC, Sih A (eds) Predation: direct and indirect impact on aquatic communities. Press of New England, Hanover, NH, p 203-224

Skilleter GA, Peterson CH (1994) Control of foraging behavior of individuals within an ecosystem context: the clam Macoma balthica and interactions between competition and siphon cropping. Oecologia 100:268-278

Sparks BL, Strayer DL (1998) Effects of low dissolved oxygen on juvenile Elliptio complanata (Bivalvia: Unionidae). J North Am Benthol Soc 17:129-134

Stanley SM (1970) Relation of shell form to life habits of the bivalvia (Mollusca). Geol Soc Am Mem 125:1-296

Tallqvist M, Sandberg-Kilpi E, Bonsdorff E (1999) Juvenile flounder, Platichthys flesus (L.), under hypoxia: effects on tolerance, ventilation rate and predation efficiency. J Exp Mar Biol Ecol 242:75-93

Theede H, Ponat A, Hiroki K, Schlieper C (1969) Studies on the resistance of marine bottom invertebrates to oxygen deficiency and hydrogen sulphide. Mar Biol 2:325-337

Thiel M, Stearns LM, Watling L (1998) Effects of green algal mats on bivalves in a New England mud flat. Helgol Meeresunters 52:15-28

Vismann B (1991) Physiology of sulphide detoxification in the isopod Saduria (Mesidotea) entomon. Mar Ecol Prog Ser 76:283-293

Vismann B (1992) Hydrogen sulphide: an important factor in the distribution of marine invertebrates in sediments. In: Bjørnestad E, Hagerman L, Jensen K (eds) Proc 12th Baltic Mar Biol Symp. Olsen \& Olsen, Fredensborg, p 169-172

Woodin SA (1982) Browsing: important in marine sedimentary environments? Spionid polychaete examples. J Exp Mar Biol Ecol 60:35-45

Zaklan SD, Ydenberg R (1997) The body size-burial depth relationship in the infaunal clam Mya arenaria. J Exp Mar Biol Ecol 215:1-17

Zwarts L (1986) Burying depth of benthic bivalve Scrobicularia plana (da Costa) in relation to siphon-cropping. J Exp Mar Biol Ecol 101:25-39

Zwarts L, Wanink J (1989) Siphon size and burying depth in deposit- and suspension-feeding benthic bivalves. Mar Biol 100:227-240

Zwarts L, Blomert AM, Spaak P, de Vries B (1994) Feeding radius, burying depth and siphon size of Macoma balthica and Scrobicularia plana. J Exp Mar Biol Ecol 183:193-212

Submitted: February 11, 2000; Accepted: August 31, 2000 Proofs received from author(s): February 22, 2001 